\title{
Common mental disorders and resilience in homeless persons
}

\author{
Transtornos mentais comuns e resiliência de pessoas em situação de rua \\ Trastornos mentales comunes y resiliencia en personas en situación de calle
}

Anna Cláudia Freire de Araújo Patrício' ORCID: 0000-0002-9310-4700

Richardson Augusto Rosendo da Silva" ORCID: 0000-0001-6290-9365

Rossini Freire de Araújo"'I ORCID: 0000-0002-8333-9872

Rôseane Ferreira da Silva"'I ORCID: 0000-0001-8908-5749

Géssica Thais de Sousa Nascimento"'I ORCID: 0000-0002-9023-6636

Thays Domingos de Brito Rodrigues"' ORCID: 0000-0002-6396-4136

Maria Amanda Pereira Leite ${ }^{\text {III }}$ ORCID: 0000-0003-1337-6077

'Universidade Federal de Uberlândia. Uberlândia, Minas Gerais, Brazil

"Universidade Federal do Rio Grande do Norte. Natal, Rio Grande do Norte, Brazil.

"I'Centro Universitário de João Pessoa. João Pessoa, Paraíba, Brazil.

How to cite this article: Patrício ACFA, Silva RAR, Araújo RF, Silva RF, Nascimento GTS, Rodrigues TDB, et al. Common mental disorders and resilience in homeless persons. Rev Bras Enferm. 2019;72(6):1526-33. doi: http://dx.doi.org/10.1590/0034-7167-2018-0541

Corresponding Author: Anna Cláudia Freire de Araújo Patrício E-mail: claudia.freirearaujo@gmail.com

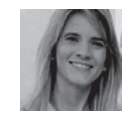

\section{ABSTRACT}

Objective: To identify common mental disorders and resilience in homeless persons. Method: Cross-sectional study with 49 homeless persons, assisted in the Casa da Acolhida Adulta and the Specialized Reference Center in a municipality in the Northeast of Brazil. Data collection performed between February and March 2018, using SRQ20 scales for common mental disorders and another for Resilience. Kruskal Wallis test, Student's T-test and Chi-Square test were used. Results: In the study, $61.2 \%$ (30) participants have poor sleep; $69.4 \%$ (34) feel nervous, tense or worried; $71.4 \%$ (35) feel unhappy; $63.3 \%$ are unable to play a useful role in their lives; $71.4 \%$ (35) have common mental disorders, and $44.9 \%$ (22) presented low resilience. Resilience influences common mental disorders, which, in turn, are influenced by gender and age. Conclusion: Professionals who assist homeless persons need to have a look directed at common mental disorders and resilience.

Descriptors: Mental Disorders; Resilience, Psychological; Homeless Persons; Mental Health; Nursing.

\section{RESUMO}

Objetivo: Rastrear transtornos mentais comuns e a resiliência de pessoas em situação de rua. Método: Estudo transversal com 49 pessoas em situação de rua, assistidas na Casa de Acolhida e Centro de Referência Especializado em município do Nordeste do Brasil. Coleta realizada entre fevereiro e março de 2018, utilizando escalas SRQ20 para transtornos mentais comuns e outra de Resiliência. Utilizaram-se os testes de Kruskal Wallis, t e Qui Quadrado. Resultados: 61,2\% (30) dormem mal, 69,4\% (34) sentem-se nervosos, tensos ou preocupados, $71,4 \%$ (35) tristes, $63,3 \%$ são incapazes de desempenhar um papel útil na sua vida, em $71,4 \%$ (35) rastreou-se transtornos mentais comuns e em $44,9 \%$ (22) baixa resiliência. A resiliência influencia os transtornos mentais comuns, os quais são influenciados pelo gênero e a idade. Conclusão: Os profissionais que assistem pessoas em situação de rua necessitam ter um olhar direcionado aos transtornos mentais comuns e resiliência.

Descritores: Transtornos Mentais; Resiliência Psicológica; Pessoas em Situação de Rua; Saúde Mental; Enfermagem.

\section{RESUMEN}

Objetivo: Identificar los trastornos mentales comunes y la resiliencia en personas en situación de calle. Método: Estudio transversal realizado con 49 personas en situación de calle, que recibían asistencia en la Casa de Acogida y Centro de Referencia Especializado, en un municipio del Nordeste de Brasil. La recolección de datos ocurrió entre febrero y marzo de 2018, siendo utilizado el SRQ-20 para los trastornos mentales comunes, y otro cuestionario para la resiliencia. Se utilizaron las pruebas de Kruskal-Wallis, ty de Qui-cuadrado. Resultados: El 61,2\% (30) de los participantes duermen mal, el 69,4\% (34) se sienten nerviosos, tensos o preocupados, el $71,4 \%$ (35) tristes, el 63,3\% son incapaces de desempeñar un papel útil en la vida, el $71,4 \%$ (35) presentan trastornos mentales comunes y el $44,9 \%$ (22) tienen baja resiliencia. La resiliencia influye en los trastornos mentales comunes, que son influenciados por el género y la edad. Conclusión: Los profesionales que asisten a personas en situación de calle necesitan considerar los trastornos mentales comunes y la resiliencia.

Descriptores: Trastornos Mentales; Resiliencia Psicológica; Personas sin Hogar; Salud Mental; Enfermería. 


\section{INTRODUCTION}

The number of people in Brazil who have their basic social rights excluded, such as education, health, employment and housing, have increased considerably, contributing to a high incidence of homeless persons ${ }^{(1)}$.

Estimates indicate that there are some 101,854 homeless persons in Brazil, and $77.02 \%$ out of this total live in municipalities with more than 100 thousand inhabitants ${ }^{(2)}$. In Brazil, homeless persons experience prejudice, intolerance, isolation, social exclusion, extreme poverty, and impaired family ties ${ }^{(3)}$.

Common mental disorders affect a third of the general population at different ages, and are responsible for $12 \%$ diseases ${ }^{(4)}$. Living conditions on the streets (violence, prejudices, discrimination, lack of privacy, lack of education and infrastructure for body care) contribute to the emergence of common mental disorders (mood, anxiety, somatization) that, in turn, may be one of the factors that contribute to the homelessness condition of a person ${ }^{(5)}$.

Studies point to a number of factors that can lead a person to live on the street, such as rupture of family ties, common mental disorders, lack of a family nucleus, violence, drugs, economic situation, or even the difficulty to be in the labor market ${ }^{(6)}$. Research conducted in João Pessoa-PB, scenario of this study, revealed use of drugs and alcohol, unemployment and rupture of family ties as reasons for becoming a homeless person ${ }^{(7)}$.

Authors point out that the prevalence of the development of common mental disorders among homeless persons is high when compared with other population groups ${ }^{(8)}$. A study conducted in Brazil with this group showed that $49.4 \%$ had some type of common mental disorder, and depression and anxiety were more frequent ${ }^{(8)}$. International research with homeless persons indicated that about $90 \%$ of them received a psychiatric diagnosis, with approximately $40 \%$ psychosis episodes and $29 \%$ abusive use of alcohol(9).

Even in the face of the precarious situation in which they live, besides feeling guilt, family absence and prejudice in society, some of these people believe that something good can happen in their lives, and through resilience they seek strength to overcome these adversities.

Resilience means the ability to recover from life adverse situations ${ }^{(10)}$, and it is expressed in the presence of risk factors; there will be no resilience without risk. Risk has the potential to predispose people and populations to negative results, and may be present in both individual and environmental characteristics. Among individual risk factors, it is possible to find characteristics as gender, genetic problems, lack of social skills, intellectual and limited psychological characteristics; environmental risk factors are characterized by life stressful events, lack of social and affective support, and low socioeconomic level(11).

In order to support and justify the development of the study, there was search for scientific production in the last five years on the subject in question on databases/virtual library, namely: Latin American and Caribbean Literature (Lilacs), PubMed, SCOPUS, CINAHL, Web of Science, Embase and Cochrane, using the descriptors in health sciences (DeCS)/Medical Subject Headings (MeSH): Resiliência Psicológica/Resilience, Psychological; Transtornos Mentais/Mental Disorders and Pessoas em Situação de Rual Homeless Persons. Deficit of studies addressing common mental disorders and resilience in homeless persons was verified ${ }^{(5)}$.
The social and academic relevance of this study focuses on the analysis of the prevalence of common mental disorders and resilience in homeless persons, influencing decision-making models in health and services that provide assistance to these people. Moreover, in Brazil, research on this subject is scarce, making the performance of this study to be pertinent ${ }^{(12)}$. In addition, the accumulation of studies in the area, aiming to demarcate this field of action, may lead to the establishment of new public policies that are based on evidence.

Considering that the number of homeless persons is increasing and that mental health is part of the individual's psychological adaptation, it is important to investigate these conditions, providing a basis for the development of confrontation strategies so that to guarantee assistance necessary to maintain their physical and mental well-being. This research emerged from the following questions: Are there common mental disorders and resilience in homeless persons? Are common mental disorders influenced by resilience? Do gender and age influence common mental disorders and resilience? Does length of homelessness influence resilience?

\section{OBJECTIVE}

To identify common mental disorders and resilience in homeless persons.

\section{METHOD}

\section{Ethical Aspects}

The research was submitted to and approved by the Research Ethics Committee, and followed the ethical principles established in Resolution 466/2012 of the National Health Council ${ }^{(13)}$.

\section{Design, study place and period}

This cross-sectional, descriptive and quantitative research was conducted with homeless persons who receive social assistance at the Casa da Acolhida Adulta and the Specialized Reference Center for Homeless Population (Centro POP), in the city of João Pessoa-PB, Brazil. The data collection was carried out during February and March 2018.

Casa da Acolhida and POP Center are institutions managed by the State Secretariat for Social Development (Sedes) in the municipality of João Pessoa-PB. They have professionals (educator, psychologist and social worker) who provide assistance and refer patients to be followed-up in other public institutions, as: Psychosocial Care Center (CAPS), hospital, health unit, and rehabilitation clinic for chemical dependents. These data collection sites were selected as reference institutions for assisting homeless persons in the city, as well as serving as teaching and research field for higher education institutions.

\section{Population or sample: inclusion and exclusion criteria}

Considering the people who remained at the research sites throughout data collection, the study population consisted of 51 homeless persons, and the sample consisted of 49 individuals, since two refused to participate in the study. It is worth mentioning that sample calculation was performed on Statdisk Software Program for Windows, considering 95\% confidence and 3\% error margin. It 
is emphasized that some issues, such as the prolonged professional strike and the subsequent renovation of one of the institutions limited the number of people who attended the services investigated throughout the study. Thus, it was not possible to enlarge the sample.

Inclusion criteria were: age equal or superior to 18 years, verbal communication capacity, and capability to contribute to the research at the moment of data collection. Those homeless persons who were not in the support houses (data collection site), were aggressive or using illicit drugs were excluded at the time of data collection.

\section{Study protocol}

Homeless persons received a prior communication about the date and procedure of data collection through the researchers, with the support of the Casa da Acolhida Adulta's and the Specialized Reference Center for Homeless Population's coordinators.

Data were collected individually by the researchers, in appropriate environment, with 40-minute mean time of instrument application per subject. The collection instrument was applied by four Nursing students (Scientific Initiation scholarship students), accompanied by a Nursing doctorate degree student on every day of data collection. In order to standardize the collection, they previously participated in training with 20-hour total workload, given by the research coordinator, and the subjects pertinent to the study object were discussed. It is worth noting that all questions of the instrument were discussed in detail with the researchers who collected data.

The instruments used for data collection consisted of two validated scales, the first one referring to common mental disorders, called Self Reporting Questionnaire (SRQ20), and the second one on Resilience. SRQ 20 scale identifies common mental disorders (insomnia, fatigue, irritability, forgetfulness, difficulty to concentrate and somatic complaints), composed of 20 questions, four referring to physical symptoms and 16 psychoemotional ones, with alternatives of "yes" or "no" answers. Score with seven or more "yes" answers was considered affirmative for the presence of common mental disorders ${ }^{(14)}$.

The resilience scale presents 25 items that encompasses five themes: serenity, perseverance, self-confidence, meaning of life and self-sufficiency. The answers range from 1 (totally disagree) to 7 (totally agree), with a minimum score of 25 and maximum of 175 points, the higher the score, the greater the resilience. Score up to 125 indicates low resilience, score of 125 to 145 indicates medium resilience, and above 145 indicates high resilience ${ }^{(15)}$. Besides these instruments, sociodemographic variables were extracted: age, gender, and length of homelessness.

For resilience scale, psychometric evaluation for instrument validation found: Kappa oscillating between discrete $(0.0-0.20)$ and moderate $(0.40-0.60)$, with $35 \%$ confidence; Cronbach's alpha of 0.85 , and Intraclass Correlation Coefficient of 0.746 , with 0.624 and 0.829 confidence interval ${ }^{(15)}$. For SRQ20 scale, Cronbach's alpha coefficient was 0.86 in its validation with Pearson's $r$ for item correlation represented by $\mathrm{p}$-value $<0.001^{(14)}$.

\section{Statistical Analysis}

Data processing was performed by the Statistical Package for the Social Sciences (SPSS), version 19.0. Kruskal Wallis test was used to verify the hypotheses: common mental disorders influence resilience classification; resilience classification is influenced by length of homelessness; age influences resilience classification. Student's T-test was used to verify the hypothesis: resilience scale score influences the common mental disorder scale score. Chi-square test was performed to test the hypotheses: common mental disorders classification is influenced by gender; resilience classification is influenced by gender; age influences the common mental disorders scale. For all tests, $p$-value $\leq 0.05$ was considered significant. A psychometric analysis of the internal consistency of the scales was performed using Cronbach's alpha, considering the value greater than 0.7 as ideal.

\section{RESULTS}

The 49 homeless persons who participated in the research had a mean age of $34.93 \pm 9.3$ years, most of them were male $(89.8 \%)$, with length of homelessness ranging from a maximum of 31 years and a minimum of three days.

Table 1 - SRQ20 scale answers that identified common mental disorders in homeless persons ( $N$ = 49), João Pessoa, Paraíba, Brazil, 2018

\begin{tabular}{|c|c|c|c|c|}
\hline \multirow{2}{*}{ Questions } & \multirow[b]{2}{*}{ Yes } & \multicolumn{2}{|c|}{ Answers } & \multirow[b]{2}{*}{ No } \\
\hline & & No & Yes & \\
\hline Do you often have headaches? & 18 & 31 & 36.7 & 63.3 \\
\hline Is your appetite poor? & 14 & 35 & 28.6 & 71.4 \\
\hline Do you sleep badly? & 30 & 19 & 61.2 & 38.8 \\
\hline Are you easily frightened? & 22 & 27 & 44.9 & 55.1 \\
\hline Do your hands shake? & 15 & 34 & 30.6 & 69.4 \\
\hline Do you feel nervous, tense, or worried? & 34 & 15 & 69.4 & 30.6 \\
\hline Is your digestion poor? & 8 & 41 & 16.3 & 83.7 \\
\hline Do you have trouble thinking clearly? & 17 & 32 & 34.7 & 65.3 \\
\hline Do you feel unhappy? & 35 & 14 & 71.4 & 28.6 \\
\hline Do you cry more than usual? & 21 & 28 & 42.9 & 57.1 \\
\hline Do you find it difficult to enjoy your daily activities? & 17 & 32 & 34.7 & 65.3 \\
\hline Do you find it difficult to make decisions? & 29 & 20 & 59.2 & 40.8 \\
\hline Does your daily work make you to suffer? & 18 & 31 & 36.7 & 63.3 \\
\hline Are you unable to play a useful role in your life? & 31 & 18 & 63.3 & 36.7 \\
\hline Have you lost interest in things? & 28 & 21 & 57.1 & 42.9 \\
\hline Do you feel you are a worthless person? & 13 & 36 & 26.5 & 73.5 \\
\hline Has the thought of ending your life been in your mind? & 18 & 31 & 36.7 & 63.3 \\
\hline Do you feel tired all the time? & 18 & 31 & 36.7 & 63.3 \\
\hline Are you easily tired? & 22 & 27 & 44.9 & 55.1 \\
\hline Do you have uncomfortable feelings in your stomach? & 12 & 37 & 24.5 & 75.5 \\
\hline
\end{tabular}


Table 2 - Absolute and relative frequency of information on resilience in homeless people (N=49), João Pessoa, Paraíba, Brazil, 2018

\begin{tabular}{|c|c|c|c|c|c|c|c|}
\hline \multirow[t]{2}{*}{ Items } & \multicolumn{3}{|c|}{$\begin{array}{c}\text { Disagree } \\
n / \%\end{array}$} & \multirow[t]{2}{*}{$\begin{array}{c}\text { *NAND } \\
\mathbf{n} / \%\end{array}$} & \multicolumn{3}{|c|}{$\begin{array}{c}\text { Agree } \\
\text { n/\% }\end{array}$} \\
\hline & TD & DLO & DLI & & ALI & ALO & TA \\
\hline When I make plans, I go ahead with them. & $3 / 6.1$ & - & $5 / 10.2$ & 2/4.1 & $9 / 18.4$ & $8 / 16.3$ & $22 / 44.9$ \\
\hline I usually deal with problems one way or another. & - & $2 / 4.1$ & $5 / 10.2$ & $6 / 12.2$ & $9 / 18.4$ & $7 / 14.3$ & $20 / 40.8$ \\
\hline I am able to depend on me more than on anyone else. & $2 / 4.1$ & $1 / 2$ & $3 / 6.1$ & $4 / 8.2$ & $10 / 20.4$ & $8 / 16.3$ & $21 / 42.9$ \\
\hline Keeping interest in things is important to me. & - & - & $3 / 6.1$ & $7 / 14.3$ & $3 / 6.1$ & $12 / 24.5$ & $24 / 49$ \\
\hline I can be on my own if I need to. & $2 / 4.1$ & $1 / 2$ & $1 / 2$ & $4 / 8.2$ & $9 / 18.4$ & $8 / 16.3$ & $29 / 49$ \\
\hline I am proud of having accomplished things in my life. & $16 / 32.7$ & $1 / 2$ & $3 / 6.1$ & $3 / 6.1$ & $6 / 12.2$ & $8 / 16.3$ & $12 / 24.5$ \\
\hline I usually accept things without much concern. & $8 / 16.3$ & $4 / 8.2$ & $11 / 22.4$ & $2 / 4.1$ & $2 / 4.1$ & $7 / 14.3$ & $15 / 30.6$ \\
\hline I am friends with myself. & $1 / 2$ & - & $3 / 6.1$ & $4 / 8.2$ & $6 / 12.2$ & $8 / 16.3$ & $27 / 55.1$ \\
\hline I feel I am able to handle several things at a time. & $7 / 14.3$ & $4 / 8.2$ & $7 / 14.3$ & $3 / 6.1$ & $7 / 14.3$ & $4 / 8.2$ & $17 / 34.7$ \\
\hline I am a determined person. & $2 / 4.1$ & $3 / 6.1$ & $5 / 10.2$ & $2 / 4.1$ & $5 / 10.2$ & $5 / 10.2$ & $27 / 55.1$ \\
\hline I rarely think about the purpose of things. & $7 / 14.3$ & $1 / 2$ & $10 / 20.4$ & $7 / 14.3$ & $10 / 20.4$ & $6 / 12.2$ & $8 / 16.3$ \\
\hline I do things one day at a time. & 2/4.1 & $1 / 2$ & 2/4.1 & $4 / 8.2$ & $11 / 22.4$ & $15 / 30.6$ & $14 / 28.6$ \\
\hline I am able to face hard times because I have experienced difficulties before. & $3 / 6.1$ & $1 / 2$ & $2 / 4.1$ & $3 / 6.1$ & $3 / 6.1$ & $10 / 20.4$ & $27 / 55.1$ \\
\hline I am a disciplined person. & $7 / 14.3$ & $1 / 2$ & $5 / 10.2$ & $4 / 8.2$ & $10 / 20.4$ & $4 / 8.2$ & $18 / 36.7$ \\
\hline I keep interest in things. & $2 / 4.1$ & $2 / 4.1$ & $5 / 10.2$ & $1 / 2$ & $9 / 18.4$ & $9 / 18.4$ & $21 / 42.9$ \\
\hline I can usually find reason to smile. & $15 / 30.6$ & $4 / 8.2$ & $5 / 10.2$ & $4 / 8.2$ & $4 / 8.2$ & $5 / 10.2$ & $12 / 24.5$ \\
\hline Believing in myself leads me to overcome difficult times. & $2 / 4.1$ & $1 / 2$ & $5 / 10.2$ & $3 / 6.1$ & $5 / 10.2$ & $11 / 22.4$ & $22 / 44.9$ \\
\hline In an emergency, I am a person who people can count on. & $1 / 2$ & - & $1 / 2$ & $8 / 16.3$ & $6 / 12.2$ & $5 / 10.2$ & $28 / 57.1$ \\
\hline I am able to usually look at a situation in several ways. & - & $1 / 2$ & $1 / 2$ & $5 / 10.2$ & $9 / 18.4$ & $12 / 24.5$ & $21 / 42.9$ \\
\hline Sometimes I oblige myself to do things, willing or not. & $6 / 12.2$ & $1 / 2$ & - & $6 / 12.2$ & $4 / 8.2$ & $9 / 18.4$ & $23 / 46.9$ \\
\hline My life has meaning. & $10 / 20.4$ & $7 / 14.3$ & $7 / 14.3$ & $2 / 4.1$ & $4 / 8.2$ & $4 / 8.2$ & $15 / 30.6$ \\
\hline I do not insist on things about which I can do nothing. & $6 / 12.2$ & $4 / 8.2$ & $3 / 6.1$ & $2 / 4.1$ & $11 / 22.4$ & $8 / 16.3$ & $15 / 30.6$ \\
\hline When I am in a difficult situation, I usually find a way out. & $2 / 4.1$ & $2 / 4.1$ & $2 / 4.1$ & $7 / 14.3$ & $9 / 18.4$ & $13 / 26.5$ & $14 / 28.6$ \\
\hline I have enough energy to do what I have to do. & $1 / 2$ & $1 / 2$ & $7 / 14.3$ & $1 / 2$ & $9 / 18.4$ & $11 / 22.4$ & $19 / 38.3$ \\
\hline It is okay if there are people who do not like me. & - & $3 / 6.1$ & $2 / 4.1$ & $5 / 10.2$ & $6 / 12.2$ & $5 / 10.2$ & $28 / 57.1$ \\
\hline
\end{tabular}

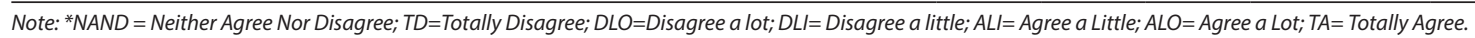

Table 3 - Identification of mental disorders and resilience in homeless persons ( $N=49)$, João Pessoa, Paraíba, Brazil, 2018.

\begin{tabular}{|c|c|c|c|}
\hline Variables & Median \pm Standard Deviation & $\mathbf{n}$ & Statistical \\
\hline Common Mental Disorders & $8.3 \pm 4.46$ & & \\
\hline Presence & & 35 & 71.4 \\
\hline Absence & & 14 & 28.6 \\
\hline Total & & 49 & 100 \\
\hline Resilience & $131.67 \pm 21.57$ & & \\
\hline Low Resilience & & 22 & 44.9 \\
\hline Medium Resilience & & 14 & 28.6 \\
\hline High Resilience & & 13 & 26.5 \\
\hline Total & & 49 & 100 \\
\hline
\end{tabular}

Table 4 - Influence of common mental disorders and resilience, resilience and length of homelessness, and age in relation to the two variables ( $\mathrm{N}=49$ ), João Pessoa, Paraíba, Brazil, 2018

\begin{tabular}{|c|c|c|c|}
\hline Hypothesis & Test & $P$ & Conduct \\
\hline Common mental disorders influence resilience classification. & Kruskal Wallis & 0.114 & It rejects the hypothesis \\
\hline Resilience classification is influenced by length of homelessness. & Kruskal Wallis & 0.157 & It rejects the hypothesis \\
\hline Resilience scale score influences common mental disorder scale score. & T Test & 0.000 & It accepts the hypothesis \\
\hline Common mental disorder classification is influenced by gender. & Chi-Square test & 0.003 & It accepts the hypothesis \\
\hline Resilience classification is influenced by gender. & Chi-Square test & 0.000 & It accepts the hypothesis \\
\hline Age influences resilience classification. & Kruskal Wallis & 0.481 & It rejects the hypothesis \\
\hline Age influences common mental disorder scale score. & Chi-Square test & 0.003 & It accepts the hypothesis \\
\hline
\end{tabular}

SRQ20 scale presented Cronbach's alpha of 0.81 (81\%), determining that the items are homogeneous and the scale consistently measures the variable in question. Table 1 shows the results of SRQ20 scale regarding the identification of common mental disorders in detail.

Cronbach's alpha regarding resilience scale presented $84 \%$ (0.84) reliability, representing good consistency. Table 2 presents resilience scale answers in order to understand it in detail.

Identification of common mental disorders and resilience are shown in Table 3.

Table 4 shows the results of the tests that verified the influence of one variable on the other.

\section{DISCUSSION}

The mean age of participants in this study was 34.93 years similar data were obtained from a study of 594 homeless persons in Ottawa, Toronto and Vancouver, where $24.4 \%$ respondents were aged between 30 and 39 years $^{(16)}$. Regarding the prevalence of homeless males, it corroborates other studies ${ }^{(17)}$.

In this study, length of homelessness ranged from three days to 31 years. In Goiânia-Goiás, a study with 150 homeless persons found that $60.7 \%$ people studied have been in this situation for less than six months, and $30.7 \%$ for more than six months ${ }^{(18)}$. A 
study in Hong Kong found that more than $80 \%$ respondents had been on the streets for more than a year ${ }^{(19)}$.

In SRQ20 scale, which is related to common mental disorders, $61.2 \%$ homeless persons say they sleep poorly. It is noteworthy that these individuals are deprived of environment that favors sleep, often sleeping in squares and sidewalks under the effects of cold, wind and rain. In the same way, a study with homeless persons in Santos-SP has been shown that it is difficult to sleep peacefully, because in addition to the climatic factors, there is no safety ${ }^{(20)}$. Insomnia is present in this context and is justified by the uncertainty of being alive the next day, besides suffering, despair and loneliness ${ }^{(21)}$.

Unhappiness was reported by $71.4 \%$ (35) individuals in this study, and may be the result of social isolation, depression and physical violence, according to an international study that identified severe social isolation in $60 \%$ participants and moderate social isolation in $28.8 \%$ respondents in a total of 260 homeless persons ${ }^{(22)}$.

Homeless persons report broken family ties, fragile relationships, impaired social support, mistrust and dishonesty that are associated with onset of unhappiness ${ }^{(23)}$. A study performed in João Pessoa-PB with homeless persons evidenced the presence of fear, devaluation, indifference, and rejection ${ }^{(7)}$.

Difficulty in making decisions is present in $59.2 \%$ participants of this study. This fact may be associated with the use of illicit drugs, social isolation, and abandonment by family and friends, which hinders the sharing of difficulties and events in personal life ${ }^{(24)}$.

In the case of common mental disorders, the study found that $63.3 \%$ homeless persons were unable to play a useful role in their lives, and it may have caused feelings of guilt, regret, and relatives and friends detachment, as well as it was reported in a study with homeless persons in Brasília-DF, who also add need to try to survive and forget these feelings with help of alcoholic beverage ${ }^{(25)}$.

The lack of meaning in life, evidenced by $20.4 \%$ (10) interviewees, may be related to the desire to die, as presented by $41.8 \%$ homeless persons in another study ${ }^{(26)}$. There was prevalence of $57.1 \%$ people in this study who lost interest in believing in a prosperous future, and it could be justified by the disillusionment in which they live ${ }^{(7)}$.

Attention to the mental health of homeless persons with common mental disorders such as depression, anxiety and stress is something that deserves special focus, since being exposed to use of illicit drug, sexual abuse and violence make them more vulnerable to health status worsening. These people are little studied and represent an increasing layer in society; therefore, deeper investigations on the subject are paramount ${ }^{(27)}$.

Regarding the resilience scale, $32.7 \%$ homeless persons totally disagreed about being proud of having accomplished something in their lives, a fact that can be associated with regret and guilt(28).

Still on resilience, $30.6 \%$ participants totally disagree about finding a reason to smile. Most homeless persons feel unhappy and have a vague look, their feelings are shattered, and they can feel relieved when they talk to someone, because they can resignify and create the possibilities of overcoming and changing by sharing ${ }^{(29)}$. In contrast, it is relevant to highlight one of the items on the resilience scale, where $30.6 \%$ individuals totally agreed that life makes sense, revealing that even after feeling of unhappiness, they believe in some change in their lives ${ }^{(30)}$.
Research with young homeless persons revealed good resilience, because despite experiencing various problems that permeate this context, they manage to make a successful transition into adulthood. Among the factors that may contribute to this situation, we can find self-esteem, intelligence and affective bonds ${ }^{(31)}$.

Common mental disorders were verified in $71.4 \%$ subjects studied, corroborating with pieces of research that reveal influence by use of illicit drug, family confrontation, sexual abuse, violence, isolation and lack of opportunities ${ }^{(22)}$.

It is worth noting that $60 \%$ general homeless population have some kind of common mental disorder, and the most prevalent are insomnia, irritability, forgetfulness, which, together with alcohol and drug addiction, cause increased mortality - by suicide or reasons related to drug use -, vulnerability, victimization of violence, and crime ${ }^{(26-31)}$.

A study conducted in the Northeast of Brazil identified risk factors for the development of common mental disorders, such as: low self-esteem, little desire to live, depression, interpersonal problems, feeling of unhappiness, aggression and violence suffered ${ }^{(32)}$. It should be noted that homeless persons who are in family conflict and with common mental disorders have weakened care in low-income countries, since social services are not always adequate to receive them ${ }^{(26)}$.

Nursing can detect abnormalities associated with the presence of common mental disorders, assist in the follow-up of those affected through support groups that can be implanted in basic health units, and can also refer them to Psychosocial Support Centers. Thus, the nurse has the capacity to attend the individual in an integral manner, and the duty to include mental health care in the basic health unit ${ }^{(33)}$.

Thus, in the context of homeless persons, the nurse can work in the shelters and at street offices. This is presented as a tool for intervention in basic care, and is regulated by Ministry of Health Ordinance No. 122/2011 $1^{(34)}$.

The National Policy for the homeless population, regulated by Federal Decree No. 07.053/2009, states that there must be a link between public policies at all levels, including health. In this way, the homeless persons of this research that receive follow-up in support houses should be referred to the service as needed ${ }^{(35)}$.

Regarding low resilience, it was presented by $44.9 \%$ homeless persons of this study. It is understood that resilience involves how to find ways to get out of or resist conflicts. Resilience deficit was also found in another study with homeless persons, and those with younger age presented greater difficulty in overcoming stressful situations ${ }^{(36)}$.

It should be noted that the resilient person presents some characteristics, such as: self-awareness, preserved self-esteem, openness and creativity, sense of humor, discipline and tolerance. Resilience may be influenced by the social structure and by the very environment into which the person is inserted ${ }^{(34)}$. Thus, the homeless persons are in a place that is unfavorable to resilience because they cannot carry out activities that give them pleasure, do not have opportunities, besides having reduced access to leisure/recreation services. In this way, they are deprived of activities that provide well-being, and the attempt to overcome adversities may be frustrated ${ }^{(37)}$.

Resilience involves protection and risk factors; the first one is that which may benefit the individual with family support, 
temper, sense of safety, positive self-image, belief and religion. In this way, the protective factors can be classified into three classes: personal, family and social. As for risk factors, it is not possible to determine that all people in situations of stress or poor living conditions will have resilience negatively affected, but there are events that may contribute, such as: death of a loved one, unemployment and illness ${ }^{(38)}$.

Resilience involves personal, family and group aspects, and can be seen positively from adverse situations which the individual is able to overcome for having understood them in a positive perspective. For those who live in fragile contexts, social support becomes relevant, such as family support, friends, programs and public policies $^{(39)}$.

In this aspect, nursing can stimulate the individuals to seek within themselves the necessary strength to achieve the four essential elements for them to present preserved resilience: connectivity (contact with others), creativity (belief in personal capacity), firmness, and flexibility (helps to bear and deal with adversity)(40).

These variables form a cascade according as resilience influences common mental disorders, as statistically proven, since ${ }^{(36)}$ homeless persons are more likely to find no means of balancing stress, and may develop diseases related to mental health, such as depression and anxiety.

In this study, it was identified that common mental disorders and resilience are influenced by gender $(p=0.003)$. It has also been observed that women are more likely to present emotional health affected, which is associated with violence that permeates the female gender ${ }^{(32)}$. Research conducted in the Federal District highlights that common mental disorders are present in $27.5 \%$ male diagnoses, and $59.6 \%$ female diagnoses ${ }^{(41)}$.

Low resilience is associated with the presence of depression and tends to be more common in women due to their physiological and hormonal conditions ${ }^{(22)}$. Age influences common mental disorders $(p=0.003)$, the same aspect found by a study in Canada, where it was identified that out of the 1103 study participants, $42 \%$ of them reported one or more suicide attempts; in this sense, precocious age at the beginning of the length of homelessness was considered a risk indicator ${ }^{(38)}$.

\section{Study limitations}

As limitations of the study, the cross-sectional design is highlighted. Taking into account the dispersion of this population and its constant growth, it is suggested that future studies with longitudinal design and sample that includes a greater number of homeless people should be performed.

\section{Contributions to the nursing and health areas and public policy}

The results of this study help professionals providing assistance to homeless persons understand that the circumstances imposed by the context in which they live contribute to mental illness, thus enabling the care directed to the real needs of this population.

\section{CONCLUSION}

The research made it possible to identify the presence of common mental disorders and low resilience among the homeless persons of this study. The statistical tests used allowed accepting the following hypotheses: resilience scale score influences common mental disorders scale score; common mental disorders classification is influenced by gender; resilience classification is influenced by gender; and age influences identification of common mental disorders. In addition, they allowed rejecting hypotheses: common mental disorders influence resilience classification; resilience classification is influenced by length of homelessness; and age influences resilience classification.

In addition, variables such as: "sleep badly"; "feeling nervous, tense or worried"; "unhappiness"; "unable to play a useful role in their lives"; "presenting common mental disorders" and "low resilience" may constitute important factors that need to be considered for promoting homeless persons' health and quality of life.

Finally, it is necessary to elaborate new studies that investigate and contribute to the use of strategies of resilience in the construction of care protocols and nursing care plans for homeless persons.

\section{REFERENCES}

1. Paiva IKS, Lira CDG, Justino JMR, Miranda MGO, Saraiva AKM. Homeless people's right to health: reflections on the problems and components. Ciênc Saúde Colet. 2016;21(8):2595-606. doi: 10.1590/1413-81232015218.06892015

2. Natalino MAC. Estimativa da População em Situação de Rua no Brasil [Internet]. Brasília: Instituto de Pesquisa Econômica Aplicada (IPEA); 2016 [cited 2018 Mar 2]. Available from: http://ipea.gov.br/portal/images/stories/PDFs/TDs/26102016td_2246.pdf

3. van Wijk LB, Mângia EF. Health care for homeless people by the network of psychosocial attention of Sé. Saúde Debate. 2017;41(115):113042. doi: 10.1590/0103-1104201711511

4. Lucchese R, Sousa K, Bonfin SP, Vera I, Santana FR. Prevalence of common mental disorders in primary health care. Acta Paul Enferm. 2014;27(3):200-7. doi: 10.1590/1982-0194201400035

5. Nilsson SF, Laursen TM, Hjorthøj C, Thorup A, Nordentoft M. Risk of psychiatric disorders in offspring of parents with a history of homelessness during childhood and adolescence in Denmark: a nationwide, register-based, cohort study. Lancet Public Health. 2017;2(12):e541-50. doi: 10.1016/S2468-2667(17)30210-4

6. Silva ICN, Santos MVS, Campos LCM, Silva DO, Porcino CA, Oliveira JF. Social representations of health care by homeless people. Rev EsC Enferm USP. 2018;52:e03314. doi: 10.1590/s1980-220×2017023703314 
7. Oliveira MRL. A rua como espaço para morar: observações sobre a apropriação dos espaços públicos pelos moradores de rua da cidade de João Pessoa-PB [Dissertação] [Internet]. João Pessoa: Universidade Federal da Paraíba, Programa de Pós-Graduação em Serviço Social; 2011 [cited 2018 Mar 2]. Available from: https://repositorio.ufpb.br/jspui/handle/tede/7216.

8. Botti NCL, Castro CG, Silva AK, Silva MF, Oliveira LC, Castro ACHOA, et al. Avaliação da ocorrência de transtornos mentais comuns entre a população de rua de Belo Horizonte. Barbarói. 2010;(33):178-93. doi: 10.17058/barbaroi.v0i0.1583

9. Zhang L, Norena M, Gadermann A, Hubley A, Russell L, Aubry T, et al. Concurrent disorders and health care utilization among homeless and vulnerably housed persons in Canada. J Dual Diagn. 2018;14(1):21-31. doi: 10.1080/15504263.2017.1392055

10. Goodhew M, Salmon AM, Marel C, Mills KL, Jauncey M. Mental health among clients of the Sydney Medically Supervised Injecting Centre (MSIC). Harm Reduct J. 2016;13(29):1-5. doi: 10.1186/s12954-016-0117-y

11. Vasconcelos IFFG. Strategy, organizational change and organizational resilience. Cad EBAPE.BR. 2017;15(spe):1-3. doi: 10.1590/1679-395170357

12. Montiel JM, Bartholomeu D, Carvalho LF, Pessotto F. Avaliação de transtornos da personalidade em moradores de rua. Psicol Ciênc Prof. 2015;35(2):488-502. doi: 10.1590/1982-370301992013

13. Ministério da Saúde (BR). Conselho Nacional de Saúde. Resolução n 466, de 12 de dezembro de 2012. Aprova diretrizes e normas regulamentadoras de pesquisa envolvendo seres humanos [Internet]. Diário Oficial da União, Brasília, 12 dez. 2012 [cited 2018 Mar 2]. Available from: http://conselho.saude.gov.br/resolucoes/2012/Reso466.pdf

14. Gonçalves DM, Stein AT, Kapczinski F. Avaliação de desempenho do Self-Reporting Questionnaire como instrumento de rastreamento psiquiátrico: um estudo comparativo com o Structured Clinical Interview for DSMIV-TR. Cad Saúde Pública. 2008;24(2):380-90. doi: 10.1590/ S0102-311X2008000200017

15. Pesce RP, Assis SG, Avanci JQ, Santos NC, Malaquias JV, Carvalhaes R. Adaptação transcultural, confiabilidade e validade da escala de resiliência. Cad Saúde Pública. 2005;21(2):436-48. doi: 10.1590/S0102-311X2005000200010

16. To MJ, Palepu A, Aubry T, Nisenbaum R, Gogosis E, Gadermann A, et al. Predictors of homelessness among vulnerably housed adults in 3 Canadian cities: a prospective cohort study. BMC Public Health. 2016;16:1041. doi: 10.1186/s12889-016-3711-8

17. Stenius-Ayoade A, Haaramo P, Erkkilä E, Marola N, Nousiainen K, Wahlbeck K, et al. Mental disorders and the use of primary health care services among homeless shelter users in the Helsinki metropolitan area, Finland. BMC Health Serv Res. 2017;17:428. doi: 10.1186/ s12913-017-2372-3

18. Barros CVL, Galdino Jr H, Rezza G, Guimarães RA, Ferreira PM, Souza CM, et al. Bio-behavioral survey of syphilis in homeless men in Central Brazil: a cross-sectional study. Cad Saúde Pública. 2018;34(6):e00033317. doi: http://dx.doi.org/10.1590/0102-311x00033317

19. Yim LC, Leung HC, Chan WC, Lam MH, Lim VW. Prevalence of mental illness among homeless people in Hong Kong. PloS One. 2015;10(10):e140940. doi: 10.1371/journal.pone.0140940

20. Andrade LP, Costa SL, Marquetti FC. A rua tem um ímã, acho que é a liberdade: potência, sofrimento e estratégias de vida entre moradores de rua na cidade de Santos, no litoral do estado de São Paulo. Saúde Soc. 2014;23(4):1248-61. doi: 10.1590/S0104-12902014000400011

21. Schmidt R, Hrenchuk C, Bopp J, Poole N. Trajectories of women's homelessness in Canada's 3 northern territories. Int J Circumpolar Health [Internet]. 2015[cited Mar 13];74(1):29778. doi: 10.3402/ijch.v74.29778

22. Riley ED, Shumway M, Knight KR, Guzman D, Cohen J, Weiser SD. Risk factors for stimulant use among homeless and unstably housed adult women. Drug Alcohol Depend. 2015;153:173-9. doi: 10.1016/j.drugalcdep.2015.05.023

23. Neves-Silva P, Martins Gl, Heller L. "We only have access as a favor, don't we?" The perception of homeless population on the human rights to water and sanitation. Cad Saúde Pública. 2018;34(3):e00024017. doi: 10.1590/0102-311x00024017

24. Jabur PAC, Campos IO, Souza TR, Paula LB. Migração e situações de rua: o uso do álcool nas ruas de Brasília. Cad Ter Ocup. 2014; 22(Supl Esp):125-33. doi: 10.4322/cto.2014.037

25. Halpern SC, Scherer JN, Roglio V, Faller S, Sordi A, Ornell F, et al . Vulnerabilidades clínicas e sociais em usuários de crack de acordo com a situação de moradia: um estudo multicêntrico de seis capitais brasileiras. Cad Saúde Pública. 2017;33(6):e00037517. doi: 10.1590/0102-311x00037517

26. Fekadu A, Hanlon C, Gebre-Eyesus E, Agedew M, Solomon H, Teferra S, et al. Burden of mental disorders and unmet needs among street homeless people in Addis Ababa, Ethiopia. BMC Med. 2014;12:138. doi: 10.1186/s12916-014-0138-x

27. Chrystal JG, Glover, DL, Young AS, Whelan F, Austin EL, Johnson NK, et al. Experience of primary care among homeless individuals with mental health conditions. PloS One. 2015;10(2):e0117395. doi: 10.1371/journal.pone.0117395

28. Macerata IM, Passos E. Intervenção com jovens em situação de rua: problematizando cuidado e controle. Psicol Soc. 2015;27(3):537-47. doi: 10.1590/1807-03102015v27n3p537

29. Santana CLA, Rosa AS, organizadores. Saúde mental das pessoas em situação de rua: conceitos e práticas para profissionais da assistência social [Internet]. 1 ${ }^{\text {a }}$ ed. São Paulo: Epidaurus Medicina e Arte; 2016 [cited 2019 Feb 7]. Available from: http://www.prefeitura.sp.gov.br/ cidade/secretarias/upload/desenvolvimento_urbano/saude_mental_pop_rua.pdf.

30. Andrade LP, Costa SL, Marquetti FC. A rua tem um ímã, acho que é a liberdade: potência, sofrimento e estratégias de vida entre moradores de rua na cidade de Santos, no litoral do estado de São Paulo. Saúde Soc. 2014;23(4):1248-61. doi: 10.1590/S0104-12902014000400011 
31. Krabbenborg MAM, Boersma SN, Wolf JRLM. A strengths based method for homeless youth: effectiveness and fidelity of Houvast. BMC Public Health. 2013;13:359. doi: 10.1186/1471-2458-13-359

32. Pinto ACS, Luna IT, Silva AA, Pinheiro PNC, Braga VAB, Souza AMA. Fatores de risco associados a problemas de saúde mental em adolescentes: revisão integrativa. Rev Esc Enferm USP. 2014;48(3):552-61. doi: 10.1590/S0080-623420140000300022

33. Loyola CMD. Mental health and psychiatric nursing: contributions to the resocialization of person in psychic suffering. Esc Anna Nery. 2017;21(3):e20170301. doi: 10.1590/2177-9465-ean-2017-0003-0001

34. Ministério da Saúde (BR). Portaria no 122, de 25 de janeiro de 2011. Define diretrizes de organização e funcionamento das Equipes de Consultório de Rua [Internet]. Diário Oficial da União, Brasília, 1 fev. 2012 [cited 2019 Feb 7]. Available from: http://bvsms.saude.gov.br/bvs/ saudelegis/gm/2012/prt0122_25_01_2012.html

35. Governo Federal do Brasil. Decreto n 7053, de 23 de dezembro de 2009. Institui a Política Nacional para a População em Situação de Rua e seu Comitê Intersetorial de Acompanhamento e Monitoramento, e dá outras providências [Internet]. Diário Oficial da União, Brasília, 24 dez. 2019 [cited 2019 Feb 7]. Available from: http://www.planalto.gov.br/ccivil_03/_ato2007-2010/2009/decreto/d7053.htm

36. Opalach C, Romaszko J, Jaracz M, Kuchta R, Borkowska A, Buciński A. Coping styles and alcohol dependence among homeless people. PloS One. 2016;11(9):e0162381. doi: 10.1371/journal.pone.0162381

37. Estêvão P, Calado A, Capucha L. Resilience: moving from a "heroic" notion to a sociological concept. Sociologia, Problemas e Práticas. 2017;85(1):9-25. doi: 10.7458/SPP20178510115

38. Kidd SA, Gaetz S, O'Grady B. The 2015 National Canadian homeless youth survey: mental health and addiction findings. Can J Psychiatry. 2017;62(7):493-500. doi: 10.1177/0706743717702076

39. Amaral-Bastos M. O conceito de resiliência na perspectiva de enfermagem. Rev Aladefe[Internet]. 2013[cited 2018 Jun 20];3(4):61-70. Available from: https://www.enfermeria21.com/revistas/aladefe/articulo/92/o-conceito-de-resiliencia-na-perspetiva-de-enfermagem/

40. Bezerra IHP, Macêdo Filho I, Costa RJLM, Sousa VJ, Carvalho MVG. População em situação de rua: um olhar da enfermagem sobre o processo saúde/doença. Enferm Rev [Internet]. 2015[cited 2018 Mar 2];18(1):3-14. Available from: http://periodicos.pucminas.br/index.php/ enfermagemrevista/article/view/9365

41. Zanello V, Silva RMC. Mental health, gender and structural violence. Rev Bioét [Internet]. 2012[cited 2018 May 28];20(2)267-79. Available from: http://revistabioetica.cfm.org.br/index.php/revista_bioetica/article/view/745/797 